\title{
Morphological Variation of Bael Fruits (Aegle marmelos (L.) Corrêa) among Five Accessions in Three Different Agro-Ecological Regions of Sri Lanka
}

\author{
C.K. Pathirana ${ }^{*}$, J.G.K.L. Gamlath ${ }^{1}$, K.W. Ketipearachchi ${ }^{1}$, P.M.C.K. Bandaranayake ${ }^{2}$, \\ W.M.T. Madhujith ${ }^{3}$ and J.P. Eeswara ${ }^{4}$
}

Postgraduate Institute of Agriculture University of Peradeniya

Sri Lanka

\begin{abstract}
Bael fruit pulp possesses delicious taste with pleasing aroma and exhibit important pharmacological attributes such as hepato-protective and anti-cancerous properties. Although, bael is popular among the general public, it is considered as an underutilized fruit species in Sri Lanka. The Fruit Research and Development Institute of Sri Lanka has identified five superior bael Accessions (Beheth Beli, Paragammana, Mawanella, Rambukkana and Polonnaruwa Supun) from diverse agro-ecological zones. In the present study, morphological diversity of the ripened fruits harvested from the five selected bael Accessions was investigated in three fruiting seasons in 2015-2017. The fruit weight, length, width, inner diameter, number of seeds, shell thickness, fruit color according to Munsell Color Chart, $L^{*}, a^{*}, b^{*}$, Chroma and Hue angle were measured and the data were statistically analyzed. The mean fruit weight was significantly high in Polonnaruwa Supun (951.86 g) followed by Rambukkana (669.14 g) and Mawanella (310.70 g) $(p<0.05)$. The accessions Beheth Beli and Paragammana had the lowest fruit sizes $138.29 \mathrm{~g}$ and $158.09 \mathrm{~g}$, respectively $(p<0.05)$. Mean number of seeds were lowest in Polonnaruwa Supun (20 per fruit) and highest in the accessions Mawanella (60.33) and Rambukkana (60 per fruit) $(p<0.05)$. The growing season has no effect either on size of fruits or number of seeds present. Three clear clusters could be identified based on fruit size, in which Polonnaruwa Supun and Rambukkana with 83.2\% similarity clustered together and Beheth Beli and Paragammana with $94.4 \%$ similarity clustered together. The accession Mawanella was separated from the rest. The shell colour was not variable among the five accessions however; flesh colour of Rambukkana was the darkest with the highest significant Chroma. The accession Polonnaruwa Supun could be considered as the best fruit type with the largest fruit size, least number of miniature seeds and appealing flesh colour for consumption as a fresh fruit, while Rambukkana fruits can be considered as the best for processing due to its flesh colour.
\end{abstract}

Keywords: Bael accessions, flesh colour, fruit colour, fruit morphology of bael, underutilized fruits

\footnotetext{
${ }^{1}$ Fruit Crop Research \& Development Institute, Peradeniya, Sri Lanka

2 Agricultural Biotechnology Centre, University of Peradeniya, Sri Lanka

3 Department of Food Science, Faculty of Agriculture, University of Peradeniya, Sri Lanka

${ }^{4}$ Department of Crop Science, Faculty of Agriculture, University of Peradeniya, Sri Lanka

* Corresponding author: ckpathirana0421@gmail.com
} 


\section{INTRODUCTION}

Bael [Aegle marmelos (L.) Corrêa], vernacular name Beli, is a medicinal fruit tree species of the family Rutaceae (Chanda et al., 2008). This species is native to India and found in Sri Lanka, Bangladesh, Pakistan, Myanmar, Thailand and Egypt (Singhal et al., 2011). Bael tree is a slow-growing medium-sized tree, and 10-15 $\mathrm{m}$ in height with spiny or non-spiny branches. The fruit is the most economically and medicinally important plant part (Benni et al., 2011) which is round, pyriform, oval or oblong in shape, containing a hard-wooden shell. The fruit is yellow to gray-greenish in color and filled with aromatic, pale-orange, sticky, sweet and resinous pulp. A total of 10-60 seeds are embedded in the pulp and covered with colorless mucilage substance (Encyclopedia of Life, 2010).

Bael fruits are consumed as fresh ripen pulp (Seth, 2003) or processed to produce items such as jam, syrup, pudding, or mixed with traditional sweets in the native countries (Baliga et al., 2011; Morton, 1987). There are numerous pharmacological properties in bael pulp such as anticancerous (Khan et al., 2002; Lambertini et al., 2004; Lampronti et al., 2003) free radical scavenging (Kamalakkannan and Prince, 2003), lipid peroxidation inhibitory effect (Venkatesh et al., 1990) and gastro-hepato protective effects (Khan and Sultana, 2009; Rajeskaran, 2009; Sidana et al., 2011). These pharmacological properties are due to the presence of bioactive phytochemicals, carotenoids, phenols, tannins, coumarins, flavonoid and terpinoidsin fruit pulp.These compounds are also present in bael leaves (Suvimol and Pranee, 2009; Maity et al., 2009; Lambole et al., 2010).

Bale shows a high morphological diversity (Singhal, 2011) and is widely grown in Sri Lanka. However, it is still considered an under-utilized fruit species in the country (Pushpakumara et al., 2007) due to the lack of research conducted to-date (Arsakularathne et al., 1985; Pushpakumara et al., 2007). None of the food and medicinal values present in bael fruits have been significantly exploited for the industrial purposes in Sri Lanka other than just the fresh consumption during the fruiting season. However, bael possesses an immense potential to be utilized as a cash crop in the economic development of the country. The superior genotypes of bael must be selected based on the fruit size, color parameters and biochemical and bioactive properties (Sharma and Dubley, 2013) to uplift it from the current under-utilized status. The Fruit Research and Development Institute (FRDI) of the Department of Agriculture, Sri Lanka has selected five superior bael trees (accessions) originated from different climatic zones for mass propagation of the fruit species. However, their morphological diversity has not been properly analyzed and documented to enable precise selection of accessions for the purpose of large scale or home garden cultivation. Therefore, the present study was conducted to assess the fruit morphological diversity of five elite bael accessions selected in Sri Lanka to lay a platform to identify the underlying diversity to plan efficient biochemical and genetic characterization studies to promote it as a profitable cash crop.

\section{MATERIALS AND METHODS}

\section{Plant material}

The five superior bael trees identified by the FRDI of Sri Lanka after conducting an island wide survey were considered in the present study. The names assigned to these accessions and coordinates of their locations are given in the Table 1. A minimum of ten fruits depending on the availability of matured ripen fruits were hand-picked from each accession in each of the three fruiting seasons (January to March in 2015, 2016 and 2017) by visiting each tree within 
two weeks of the peak fruiting season. The fruits were placed in boxes and moved to the laboratory and the data collection was completed within 24 hours of harvesting.

Table 1. Bael accessions used in the study and their coordinates.

\begin{tabular}{lcc}
\hline Name of the Bael accession & Location, District & Coordinates (N,E) \\
\hline Beheth Beli & Gannoruwa, Kandy & $7.277006^{\circ}, 80.595299^{\circ}$ \\
Paragammana & Paragammana Temple, Kegalle & $7.237381^{\circ}, 80.362452^{\circ}$ \\
Mawanella & Mawanella, Kegalle & $7.250664^{\circ}, 80.452431^{\circ}$ \\
Rambukkana & Rambukkana Church, Kegalle & $7.323879^{\circ}, 80.398160^{\circ}$ \\
Polonnaruwa Supun & Nirdeshagama, Polonnaruwa & $7.880910^{\circ}, 80.940870^{\circ}$ \\
\hline
\end{tabular}

\section{Assessment of the fruit size variation and number of seeds}

The fruit weight was measured using a top loading balance. The fruit length and width were measured using a meter ruler and the fruit perimeter was measured using a thread. The fruits were cut-opened horizontally at the central horizontal axis and inner diameter was measured. The pulp was removed for seed counting. The shell thickness was obtained at six different places using a vernier caliper. The number of seeds was counted from the removed flesh of each fruit.

\section{Assessment of the fruit color variation}

The fruit color was categorically measured with reference to the Munsell Color Chart (MCC). The same set of fruits were subjected to the measurement of quantitative color metrics $\mathrm{L}^{*}$ (darkness or lightness, $-\mathrm{L}^{*}$ : darker/blackish, $+\mathrm{L}^{*}$ : lighter/whitish), a* (greenness or redness, $\mathrm{a}^{*}$ : greenish, $+\mathrm{a}^{*}$ : reddish) and $\mathrm{b}^{*}$ (blueness or yellowness, $-\mathrm{b}^{*}$ : blueness, $+\mathrm{b}^{*}$ : yellowness) (CR-10, Konika Minolta, Tokyo, Japan). The Munsell Color Chart readings and the $\mathrm{L}^{*}, \mathrm{a}^{*}$ and $b^{*}$ were measured for the flesh in cut-open fruits. The Chroma $\left(\mathrm{C}^{*}\right)$ and Hue angle $\left(\mathrm{h}^{*}\right)$ of the shell and flesh colors were calculated using the following equations 1 and 2.

$C^{*}=\sqrt{a^{2}+b^{2}}$

$\mathrm{h}^{*}=\tan ^{-1}\left[\frac{\mathrm{b}}{\mathrm{a}}\right]$

\section{Data analyses}

The size measurements, shell thickness and number of seeds and quantitative color metrics $\mathrm{L}^{*}$, $a^{*}, b^{*}, C^{*}$ and $h^{*}$ of the fruits collected in three fruiting seasons were subjected to General Linear Model (GLM) Procedure in the SAS software package (SAS 9.1; SAS Institute, Cary, NC, USA). The significant mean differences were obtained using Least Square (LS) means/probabilities of difference (pdiff) option. The fruit size parameters, namely, weight, length, perimeter and inner diameter were subjected to Principal Component (PC) Analysis. The PC scores were used in cluster analysis followed by the dendrogram construction using Single Linkage and Squared Euclidian Distance in the statistical package Minitab 16 (Minitab Inc., USA). The first two PCs were used to draw the scatter plot to depict the spatial variation of fruit sizes of the five bael accessions. The Pearson's Correlation Coefficients (r) were 
calculated for fruit size parameters, number of seeds and shell thickness using Corr Procedure in SAS. The PCCs were also calculated for qualitative color metrics using the same procedure.

\section{RESULTS}

\section{Diversity of the fruit size}

The mean fruit weight (average of three fruiting seasons) was the highest $(P<0.05)$ in Polonnaruwa Supun (951.86 g) followed by Rambukkana (669.14 g) and Mawanella (310.7 g). The accessions Beheth Beli and Paragammana exhibited the lowest fruit sizes (138.29 g and $158.09 \mathrm{~g}$, respectively) but they were not significantly different from each other $(P>0.05)$. Although the mean fruit weight of Polonnaruwa Supun was higher $(P<0.05)$ than that of Rambukkana, the mean fruit length, width, perimeter and inner diameter were not significantly different among them $(P>0.05)$.The fruits of accession Mawanella demonstrated a lower mean fruit length, width, perimeter and inner diameter $(P<0.05)$ than those observed for fruits of Rambukkana and Polonnaruwa Supun. The mean fruit size was the lowest in Beheth Beli and Paragammana $(P<0.05$; Table 2$)$. The mean number of seeds per fruit (average of three fruiting seasons) was the lowest $(P<0.05)$ in Polonnaruwa Supun $(19.7)$ and highest in the accession Mawanella (60.3) and Rambukkana (59.7). The mean number of seeds per fruit of the accession Beheth Beli (50.3) was significantly different $(P<0.05)$ to that of Paragammana (44.8) $(P<0.05$; Table 2). The seeds present in Polonnaruwa Supun were shrunken, small and sterile. All the other accessions possessed fully developed and fertile seeds, which were morphologically similar. The thickness of the hard shell of the bael fruits was not highly variable among the five elite bael accessions. The mean shell thickness of Beheth Beli was the highest $(0.4 \mathrm{~cm})$ compared to that of the rest $(0.3 \mathrm{~cm})(P<0.05$; Table 2$)$. The images of the representative fruits and their cross sections of five bael accessions are given in Figure1.

The cluster analysis and constructed dendrogram based on the five PCs calculated based on fruit weight, length, width, perimeter and inner diameter revealed that the fruits of Beheth Beli and Paragammana were $94.4 \%$ similar and Polonnaruwa Supun and Rambukkanawere $83.2 \%$ similar to each other. Three clear fruit size clusters could be seen in which Polonnaruwa Supun and Rambukkana and Beheth Beli and Paragammana clustered together separately, while Mawanella clustered separately at $80 \%$ of morphological similarity coefficient (Figure 2). The scatter plot drawn between two major PCs showed similar grouping supporting the presence of three clusters for fruit size variation (Figure 3).

\section{Correlation between fruit size parameters and number of seeds}

The fruit weight, length, width, perimeter and inner diameter were very positively and significantly correlated to each other $(r>0.9 ; P<0.05)$. The number of seeds was negatively correlated with fruit weight $(\mathrm{r}=-0.5 ; P<0.05)$. Although no other significant correlations detected, it is noteworthy that the number of seeds exhibited negative correlation with other fruit size parameters. The shell thickness was negatively correlated with fruit size parameters ( $\mathrm{r}=-0.4$ to $-0.5 ; P<0.05)$. The shell thickness and number of seeds were not correlated to each other $(P>0.05$; Table 3$)$. 
Table 2. Means of the size parameters of the bael fruits obtained from the five accessions in three years.

\begin{tabular}{|c|c|c|c|c|c|c|c|c|}
\hline $\begin{array}{l}\text { Yea } \\
\mathbf{r}\end{array}$ & Bael accession & $\begin{array}{l}\text { Weight } \\
\text { (g) }\end{array}$ & $\begin{array}{l}\text { Lengt } \\
h(\mathrm{~cm})\end{array}$ & $\begin{array}{l}\text { Width } \\
\text { (cm) }\end{array}$ & $\begin{array}{l}\text { Perimeter } \\
\text { (cm) }\end{array}$ & $\begin{array}{c}\text { Inner } \\
\text { diameter } \\
(\mathrm{cm})\end{array}$ & $\begin{array}{c}\text { No. of } \\
\text { seeds } \\
\text { per } \\
\text { fruit }\end{array}$ & $\begin{array}{c}\text { Shell } \\
\text { thickness } \\
(\mathrm{cm})\end{array}$ \\
\hline \multirow[t]{5}{*}{2015} & Beheth Beli & $119.9^{c}$ & $5.78^{\mathrm{c}}$ & $5.61^{\mathrm{c}}$ & $22.67^{\mathrm{c}}$ & $4.80^{\mathrm{c}}$ & $49.0^{\mathrm{b}}$ & $0.4^{\mathrm{a}}$ \\
\hline & Paragammana & $129.7^{\mathrm{c}}$ & $5.91^{\mathrm{c}}$ & $5.85^{\mathrm{c}}$ & $23.60^{c}$ & $5.24^{c}$ & $44.4^{\mathrm{b}}$ & $0.3^{\mathrm{b}}$ \\
\hline & Mawanella & $320.3^{c}$ & $6.75^{\mathrm{b}}$ & $7.91^{\mathrm{b}}$ & $31.67^{\mathrm{b}}$ & $7.30^{\mathrm{a}}$ & $58.7^{\mathrm{a}}$ & $0.3^{\mathrm{b}}$ \\
\hline & Rambukkana & $659.3^{\mathrm{b}}$ & $9.14^{\mathrm{a}}$ & $9.50^{\mathrm{a}}$ & $38.33^{\mathrm{a}}$ & $8.90^{\mathrm{a}}$ & $58.0^{\mathrm{a}}$ & $0.3^{\mathrm{b}}$ \\
\hline & $\begin{array}{l}\text { Polonnaruwa } \\
\text { Supun }\end{array}$ & $965.4^{\mathrm{a}}$ & $9.35^{\mathrm{a}}$ & $8.47^{\mathrm{a}}$ & $34.00^{\mathrm{a}}$ & $7.87^{\mathrm{a}}$ & $19.0^{c}$ & $0.3^{\mathrm{b}}$ \\
\hline \multirow[t]{5}{*}{2016} & Beheth Beli & $159.3^{\mathrm{c}}$ & $5.54^{\mathrm{c}}$ & $5.79^{c}$ & $21.33^{c}$ & $4.97^{\mathrm{c}}$ & $50.7^{b}$ & $0.4^{\mathrm{a}}$ \\
\hline & Paragammana & $174.6^{\mathrm{c}}$ & $6.42^{\mathrm{c}}$ & $6.02^{\mathrm{c}}$ & $24.00^{c}$ & $5.40^{\mathrm{c}}$ & $45.0^{\mathrm{b}}$ & $0.3^{\mathrm{b}}$ \\
\hline & Mawanella & $321.9^{c}$ & $7.66^{\mathrm{b}}$ & $7.04^{\mathrm{b}}$ & $28.00^{\mathrm{b}}$ & $6.43^{\mathrm{b}}$ & $60.7^{\mathrm{a}}$ & $0.3^{\mathrm{b}}$ \\
\hline & Rambukkana & $627.8^{\mathrm{b}}$ & $9.91^{\mathrm{a}}$ & $9.34^{\mathrm{a}}$ & $37.33^{\mathrm{a}}$ & $8.73^{\mathrm{a}}$ & $60.0^{\mathrm{a}}$ & $0.3^{\mathrm{b}}$ \\
\hline & $\begin{array}{l}\text { Polonnaruwa } \\
\text { Supun }\end{array}$ & $897.0^{\mathrm{a}}$ & $10.48^{\mathrm{a}}$ & $9.68^{\mathrm{a}}$ & $36.00^{\mathrm{a}}$ & $9.07^{\mathrm{a}}$ & $20.0^{\mathrm{c}}$ & $0.3^{\mathrm{b}}$ \\
\hline \multirow[t]{5}{*}{2017} & Beheth Beli & $135.7^{\mathrm{c}}$ & $5.64^{\mathrm{c}}$ & $5.33^{\mathrm{c}}$ & $21.33^{\mathrm{c}}$ & $4.53^{\mathrm{c}}$ & $51.3^{\mathrm{b}}$ & $0.4^{\mathrm{a}}$ \\
\hline & Paragammana & $170.0^{c}$ & $5.57^{\mathrm{c}}$ & $5.24^{\mathrm{c}}$ & $21.00^{c}$ & $4.63^{c}$ & $45.0^{\mathrm{b}}$ & $0.3^{\mathrm{b}}$ \\
\hline & Mawanella & $290.0^{c}$ & $7.63^{\mathrm{b}}$ & $6.79^{\mathrm{b}}$ & $27.33^{\mathrm{b}}$ & $6.17^{\mathrm{b}}$ & $61.7^{\mathrm{a}}$ & $0.3^{\mathrm{b}}$ \\
\hline & Rambukkana & $720.4^{b}$ & $10.54^{\mathrm{a}}$ & $8.76^{\mathrm{a}}$ & $35.33^{\mathrm{a}}$ & $8.17^{\mathrm{a}}$ & $61.0^{\mathrm{a}}$ & $0.3^{\mathrm{b}}$ \\
\hline & $\begin{array}{l}\text { Polonnaruwa } \\
\text { Supun }\end{array}$ & $993.3^{\mathrm{a}}$ & $10.50^{\mathrm{a}}$ & $10.21^{\mathrm{a}}$ & $40.67^{\mathrm{a}}$ & $9.60^{\mathrm{a}}$ & $20.0^{\mathrm{c}}$ & $0.3^{\mathrm{b}}$ \\
\hline
\end{tabular}

Within a column, means denoted with same letters are not significantly different at $P=0.05$.

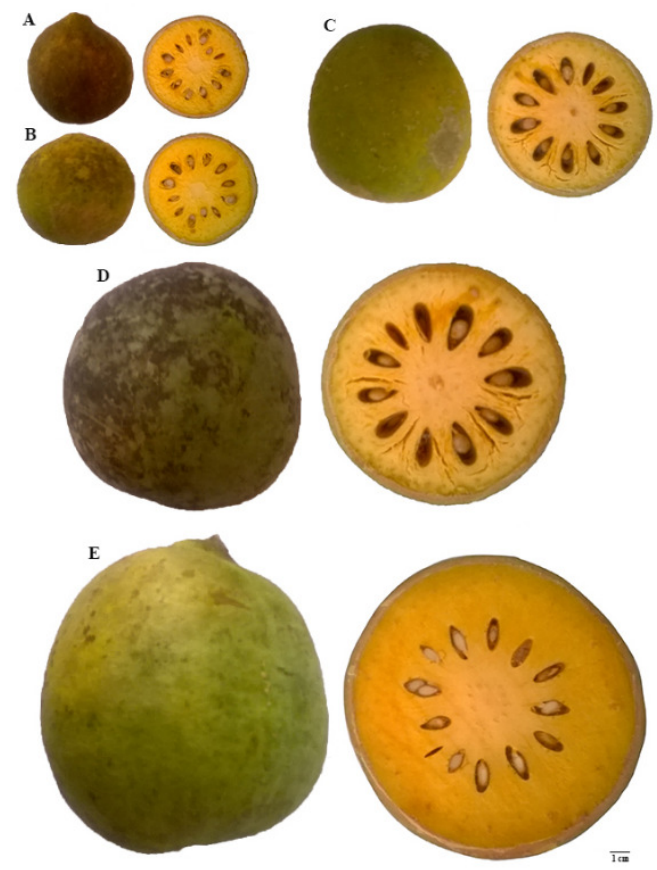

Figure 1. Variation of the fruit morphology in five bael accessions. The fruit and cross section of the fruit are shown side by side. A: Beheth Beli, B: Paragammana, C: Mawanella, D: Rambukkana, E: Polonnaruwa Supun. 


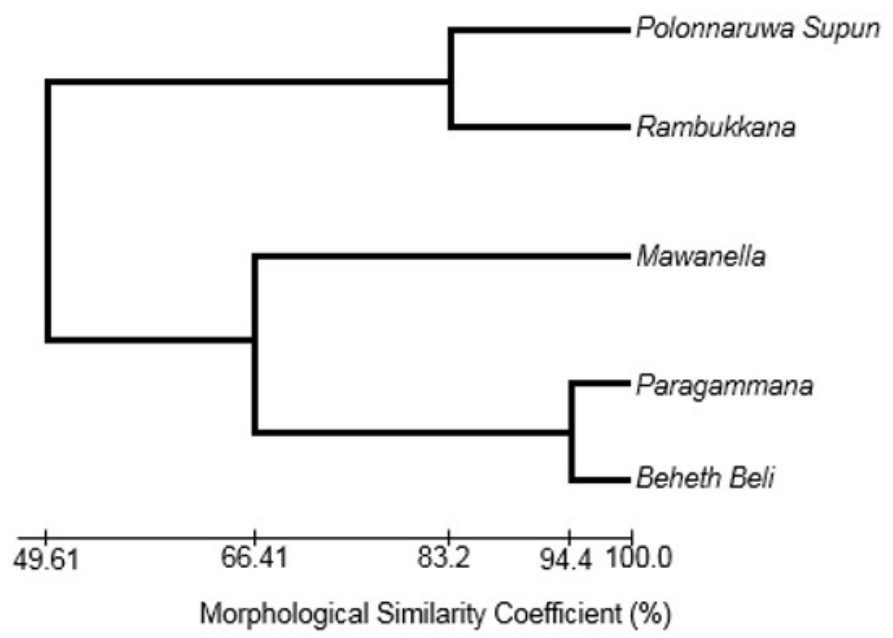

Figure 2. The dendrogram showing diversity of fruit size in five bael accessions.

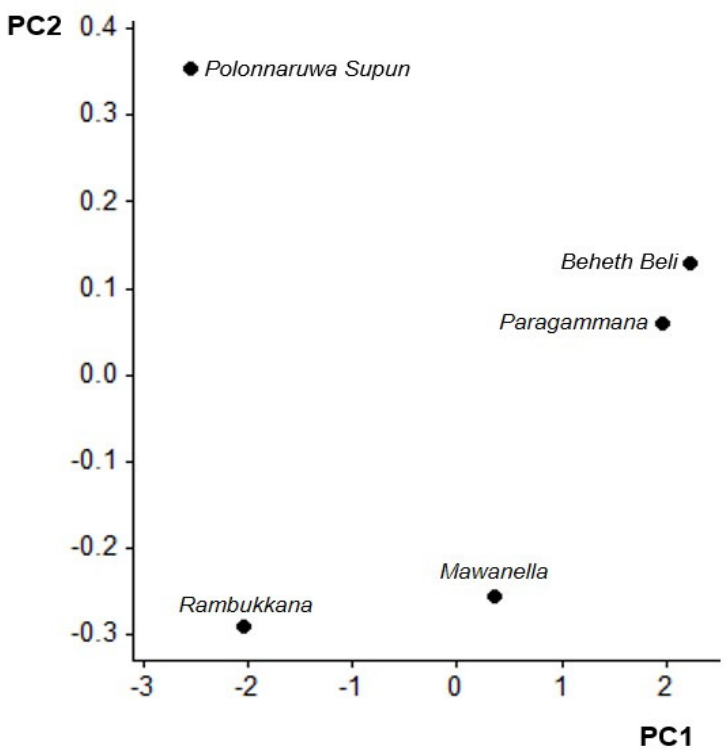

Figure 3. Scatter plot between PC1 and PC2 of fruit size variables depicting the morphological diversity of the fruits in five bael accessions; $\mathrm{PC}=$ principal component.

\section{Variation in external and flesh colors of the fruits}

The representative classes of the bael fruits of the five accessions were marginally variable according to the MCC Readings. The overall external color of Beheth Beli was darker (10YR 
4/4 in MCC) compared to other classes (5Y classes). The flesh color of all the accessions was monomorphic and fallen in the class $2.5 \mathrm{Y} 7 / 8$ in the MCC (Table 4).

Table 3. Pearson Correlation coefficients among fruit parameters.

\begin{tabular}{lcccccc}
\hline & $\begin{array}{c}\text { Weight } \\
(\mathrm{g})\end{array}$ & $\begin{array}{c}\text { Length } \\
(\mathrm{cm})\end{array}$ & $\begin{array}{c}\text { Width } \\
(\mathrm{cm})\end{array}$ & $\begin{array}{c}\text { Perimeter } \\
(\mathrm{cm})\end{array}$ & $\begin{array}{c}\text { Inner diameter } \\
(\mathrm{cm})\end{array}$ & $\begin{array}{c}\text { No. of } \\
\text { seeds }\end{array}$ \\
\hline Length $(\mathrm{cm})$ & $0.9^{\dagger}$ & & & & & \\
Width $(\mathrm{cm})$ & $0.9^{\dagger}$ & $0.9^{\dagger}$ & & & & \\
Perimeter $(\mathrm{cm})$ & $0.9^{\dagger}$ & $0.9^{\dagger}$ & & & & \\
Inner diameter $(\mathrm{cm})$ & $0.9^{\dagger}$ & $0.9^{\dagger}$ & $1^{\dagger}$ & $1^{\dagger}$ & & \\
No. of seeds & $-0.5^{\dagger}$ & -0.3 & -0.3 & -0.2 & -0.3 & \\
Shell thickness $(\mathrm{cm})$ & $-0.4^{\dagger}$ & $-0.5^{\dagger}$ & $-0.5^{\dagger}$ & $-0.5^{\dagger}$ & $-0.5^{\dagger}$ & 0.1 \\
\hline
\end{tabular}

†ignificant at $P<0.05$

Table 4. Qualitative variation of the external and flesh colors of bael fruits.

\begin{tabular}{lcc}
\hline Bael accession & External color & Flesh color \\
\hline Beheth Beli & $10 \mathrm{YR} 4 / 4$ & \\
Paragammana & $5 \mathrm{Y} 5 / 4$ & $2.5 \mathrm{Y} 7 / 8$ \\
Mawanella & $5 \mathrm{Y} 5 / 6$ & \\
Rambukkana & $5 \mathrm{Y} 4 / 4$ & \\
Polonnaruwa Supun & $5 \mathrm{Y} 6 / 6$ & \\
\hline
\end{tabular}

Although the MCC readings revealed a narrow diversity of external and flesh colors, the quantitative color metrics $\mathrm{L}^{*}, \mathrm{a}^{*}, \mathrm{~b}^{*}, \mathrm{C}^{*}$ and $\mathrm{h}^{*}$ captured the color variation observed in a more precise manner (Table 5). For example, external color of fruits of Paragammana was the darkest (blackish), reddish and bluish compared to the rest. The overall color (indicated by $\mathrm{C}^{*}$ ) was more intense in the fruits of Paragammana $\left(\mathrm{C}^{*}=36.2\right)$ compared to the rest. The darker flesh was observed in Rambukkana $h\left(\mathrm{~L}^{*}=-125.6\right)$ with the highest $\mathrm{C}^{*}$ (31.3). The $\mathrm{h}^{*}$ of flesh color was similar among the flesh samples of five accessions (Table 4). The correlation among the color metrics of external and flesh colors revealed that they were correlated $(P<0.05)$ within shell or flesh, but not correlated $(P>0.05)$ across the tissues (Table 6).

Table 5. Quantitative variation of the external and flesh colors of bael fruits.

\begin{tabular}{|c|c|c|c|c|c|c|c|c|c|c|}
\hline \multirow{2}{*}{ Bael accession } & \multicolumn{5}{|c|}{ External color } & \multicolumn{5}{|c|}{ Flesh color } \\
\hline & $\mathbf{L}^{*}$ & $\mathbf{a}^{*}$ & $\mathbf{b}^{*}$ & $\mathbf{C}^{*}$ & h* & $\mathbf{L}^{*}$ & $a^{*}$ & $\mathbf{b}^{*}$ & $\mathbf{C}^{*}$ & h* \\
\hline & & & & & & & & & 27. & \\
\hline Beheth Beli & -35.1 & 5.6 & 9.0 & 10.6 & 1.0 & -99.9 & 26.9 & 2.6 & $\begin{array}{c}0 \\
26 .\end{array}$ & 0.1 \\
\hline Paragammana & -118.3 & 20.2 & -30.1 & 36.2 & -1.0 & -115.9 & 24.0 & -10.0 & 0 & -0.4 \\
\hline Mawanella & -29.0 & 8.2 & 6.9 & 10.7 & 0.7 & -104.0 & 27.2 & 0.6 & $\begin{array}{c}27 . \\
2\end{array}$ & 0.0 \\
\hline Rambukkana & -82.9 & 13.4 & -9.2 & 16.3 & -0.6 & -125.6 & 20.8 & -23.5 & $\begin{array}{c}31 \\
3\end{array}$ & -0.8 \\
\hline Polonnaruwa & & & & & & & & & 25 . & \\
\hline Supun & -32.1 & 1.1 & 1.8 & 2.1 & 1.0 & -106.7 & 24.7 & -5.4 & 3 & -0.2 \\
\hline
\end{tabular}


Table 6. Pearson Correlation coefficients among quantitative fruit color parameters.

\begin{tabular}{|c|c|c|c|c|c|c|c|c|c|}
\hline & ECL* & ECa* & $\mathbf{E C b}^{*}$ & ECC $*$ & ECh* & FCL* & $\mathbf{F C a}^{*}$ & $\mathbf{F C b}^{*}$ & FCC* \\
\hline $\mathrm{ECa}^{*}$ & $-0.9^{\dagger}$ & & & & & & & & \\
\hline $\mathrm{ECb}^{*}$ & $1^{\dagger}$ & $-0.9^{\dagger}$ & & & & & & & \\
\hline $\mathrm{ECC}^{*}$ & $-0.9^{\dagger}$ & $1^{\dagger}$ & $-0.9^{\dagger}$ & & & & & & \\
\hline $\mathrm{ECh}^{*}$ & $1^{\dagger}$ & $-0.9^{\dagger}$ & $0.9^{\dagger}$ & -0.9 & & & & & \\
\hline FCL* & 0.8 & -0.7 & 0.7 & -0.5 & 0.9 & & & & \\
\hline $\mathrm{FCa}^{*}$ & 0.6 & -0.5 & 0.6 & -0.3 & 0.7 & $1^{\dagger}$ & & & \\
\hline $\mathrm{FCb}^{*}$ & 0.7 & -0.5 & 0.6 & -0.3 & 0.7 & $1^{\dagger}$ & $1^{\dagger}$ & & \\
\hline $\mathrm{FCC}^{*}$ & -0.2 & 0.3 & -0.2 & 0.4 & -0.4 & -0.7 & -0.6 & $-0.7^{\dagger}$ & \\
\hline $\mathrm{FCh} *$ & 0.7 & -0.6 & 0.6 & -0.4 & 0.8 & $1^{\dagger}$ & $1^{\dagger}$ & $1^{\dagger}$ & $-0.7^{\dagger}$ \\
\hline
\end{tabular}

\section{DISCUSSION}

The fruit size of bael was highly variable among the five elite accessions selected in Sri Lanka. The accessions Polonnaruwa Supun and Rambukkana could be recommended for cultivation purposes to obtain the largest fruits to promote fresh fruit market, industrial value added products and the extraction of phytochemicals (Table 2 and 3). Similar to Beheth Beli and Paragammana, the smaller size fruits, have been recorded in well-established fruit crops such as peach (De Souza et al., 1998), apple (Wertheim et al., 1986), cherry (Demirsoy and Demirsoy, 2004) and kiwifruit (Cheng et al., 2004). The accession Polonnaruwa Supun can be specifically recommended for fresh fruit market and industrial purposes due to its low number of seeds per fruit (Tables 2 and 3). Moreover, the seeds present in Polonnaruwa Supun are small, shrunken and sterile, demonstrating its readily applicable nature in fresh consumption and confectionary purposes. The seedless or few seeded fruits cultivars are useful in industrial purposes as explained in citrus (Vardi et al., 2008), apple (Yao et al., 2001) and pomegranate (Stover and Mercure, 2007).

The seasonal variation of fruit size parameters is not significant for bael (Table 2) explaining the higher genetic effect on determining the fruit size in bael. This is a very encouraging sign for genetic studies as insignificant environmental affects cause higher probability of detecting underlying genes and quantitative trait loci (QTLs) deciding the fruit size as explained in Zhang et al. (2010). The cluster analysis based on the calculated PCs using fruit size parameters are very important as PCs can remove the co-linearity effect and provide more robust clusters in depicted dendrogram. The scatter plot between the two major PCs further supported the clusters obtained and thereby accessions could be specifically selected for industrial purposes.

The higher correlations observed among the fruit parameters (Table 3) implied that the fruit size and geometry of bael fruits are governed by common genetic mechanisms. However, the number of seeds found to be negatively correlated with fruit size indicating that breeding efforts to increase the fruit size should be targeted towards selecting cultivars with less number of seeds. The negative correlation between number of seeds and fruit size has been reported in other fruit species (Alonso-Blanco et al., 1998). The shell thickness had a negative correlation with fruit size indicating that breeding efforts should be planned to reduce the shell thickness in bael cultivars. The insignificant correlation between the number of seeds and shell thickness 
hints the possibility of having two independent molecular mechanisms for shell development and shell formation, which could be an interesting future direction for molecular genetic studies on bael.

The color variation of shell and flesh among the fruits of five bael accessions were less diverse implying that early domestication events of bael has been targeted more on appealing colors in addition to the size and taste. The color chart readings such as MCC system used in the present study were not able to capture the variation sufficiently (Table 4). Therefore, color metrics $\mathrm{L}^{*}, \mathrm{a}^{*}, \mathrm{~b}^{*} \mathrm{C}^{*}$ and $\mathrm{h}^{*}$ (Table 5) could be recommended to document the fruit colors of bael accessions/cultivars for commercial grading purposes. It would also be interesting to study the dynamic developmental patterns of these color metrics with respect to the fruit development and ripening till complete maturity and just before harvesting and processing. The presence of a non-significant correlation between shell color and flesh color (Table 6) indicated the presence of two independent mechanisms for color development is these two tissue types.

\section{CONCLUSIONS}

The assessment of the morphological diversity of the ripen fruits of the five bael accessions in Sri Lanka revealed that the accessions Polonnaruwa Supun and Rambukkana possess the largest fruits compared to Beheth Beli, Paragammana and Mawanella. The accession Polonnaruwa Supun possess the least number of seeds that are also small and sterile. Fruits in Rambukkana accession possesses the darkest flesh with the highest Chroma implying its applicability in producing value added products such as jam and syrup, without any added artificial colorants. The morphological diversity assessment carried out could be readily employed to recommend the cultivars for growers, plan biochemical and genetic studies to detect the underlying biochemical compounds and genes, and uplift bael as a cash crop from its present under-utilized status in Sri Lanka.

\section{ACKNOLEDGEMENT}

National Science Foundation, Sri Lanka Research Grant (RG/2015/BT/05)

\section{REFERENCES}

Alonso-Blanco, C., Blankestijn-de Vries, H., Hanhart, C.J. and Koornneef, M. (1998). Natural allelic variation at seed size loci in relation to other life history traits of Arabidopsis thaliana.Proc. Natl. Acad. Sci. U.S.A. 96(8), 4710-4717.

Arseculeratne, S.N., Gunatilaka, A.A.L. and Panabokke, R.G. (1985). Studies on medicinal plants of Sri Lanka. Part 14: Toxicity of some traditional medicinal herbs. J. Ethnopharmacol. $13,323-335$.

Baliga, M.S., Bhat, H.P., Joseph, N. and Fazal, F. (2011). Phytochemistry and medicinal uses of the bael fruit (AeglemarmelosL. Correa): A concise review. Food Res. Int. 44, 1768-1775.

Benni, J.M., Jayanthi, M.K. and Suresha, R.N. (2011). Evaluation of the anti-inflammatory activity of Aeglemarmelos (Bilwa) root. Indian J. Pharmacol. 43(4), 393-397. 
Chanda, R., Ghosh, A., Mitra, T., Mohanty, J.P., Bhuyan, N. and Pawankar, G. (2008). Phytochemical and pharmacological activity of Aeglemarmelos as a potential medicinal plant: An overview. The Internet J. Pharmacol.6(1), 3.

Cheng, C.H., Seal, A.G., Bolding, H.L., Marsh, K.B., MacRae, E.A., Murphy, S.J. and Ferguson, A.R. (2004). Inheritance of taste characters and fruit size and number in a diploid Actinidiachinensis (kiwifruit) population. Euphytica.138(2), 185-195.

De Souza, V.A.B., Byrne, D.H. and Taylor, J.F. (1998). Heritability, genetic and phenotypic correlations, and predicted selection response of quantitative traits in peach: ii. An analysis of several fruit traits.J. Am. Soc. Hortic. Sci.123(4), 604-611.

Demirsoy, A. and Demirsoy, L. (2004). A study on the relationships between some fruit characteristics in cherries. Fruits. 59(3), 219-223.

Encylopedia of Life (2010). Description Missouri Botanical Garden, 4344 Shaw Boulevard, St. Louis, MO, 63110 USA. [Accessed on 15.08.2018]. Available at http://eol.org/data_objects/5002722.

Kamalakkannan, N. and Prince, P.S. (2003). Hypoglycaemic effect of water extracts of Aeglemarmelos fruits in streptozotocin diabetic rats. J. Ethnopharmacol. 87, 207-210.

Khan, M.T.H., Lampronti, I., Martello, D., Bianchi, N., Jabbar, S., Choudhuri, M.S., Datta, B.K. and Gambari, R. (2002). Identification of pyrogallol as an antiproliferative compound present in extracts from the medicinal plant Emblicaofficinalis: effects on in vitro cell growth of human tumor cell lines. Int. J. Oncol. 21, 87-192.

Khan, T.H. and Sultana, S. (2009). Antioxidant and hepato-protective potential of Aeglemarmelos $\mathrm{CCL}_{4}$-induced oxidative stress and early tumor events.J. Enzyme Inhib. Med. Chem. 24, 320-327.

Lambertini, E., Piva, R., Khan, M.T.H., Lampronti, I., Bianchi, N., Borgatti, M. and Gambari, R. (2004). Effects of extracts from Bangladeshi medicinal plants on in vitro proliferation of human breast cancer cell lines and expression of estrogen receptor alpha gene. Int. J. Oncol. 24, 419-423.

Lambole, V.B., Murti, K., Kumar, U., Sandipkumar, B.P. and Gajera, V. (2010). Phytopharmacological properties of Aeglemarmelos as a potential medicinal tree: an overview. Int. J. Pharm. Sci. Rev. Res. 5(2), 67-72.

Lampronti, I., Martello, D., Bianchi, N., Borgatti, M., Lambertini, E. and Piva, R. (2003). In vitroantiproliferative effects on human tumor cell lines of extracts from the Bangladeshi medicinal plant Aeglemarmelos Correa. Phytomedicine. 10, 300-308

Maity, P., Hansda, D., Bandyipadhyay, Y. and Mishra, D.K. (2009). Biological activities of crude extracts and chemical constituents of baelAeglemarmelos (L.) Corr. Indian Journal of Experimental Biology.47, 849-861. 
Morton, J.F. (1987). Fruits of Warm Climates, Creative Resource Systems Inc, Winterville, NC.

Pushpakumara, D.K.N.G. (2007). Beli: Aeglemarmelos(L.) Correa: In: Pushpakumara, D.K.N.G., Gunasena H.P.M. and Sing, V.P. (Eds.) Underutilized fruit trees in Sri Lanka. Volume 1.World Agroforestry Centre, South Asia Office, New Delhi, India. 249-276.

Rajeskaran, C. (2009). Studies on hepatoprotective activity of methanolic 388 extracts of fruit pulp of Aeglemarmelos (L.) Corr. Journal of Pharmacy 389 Research. 2, 1419-1423.

Seth, M.K. (2003). Trees and their economic importance. Bot. Rev. 69(4), 321-376.

Sharma, N. and Dubley, W. (2013). History and taxonomy of Aeglemarmelos: a review. Int. J. Pure App. Biosci.1(6), 7-13.

Sidana, J., Deswal, G., Nain, P. and Arora, K. (2011). Liver toxicity and hepatoprotective herbs. Int. J. Pharm. Sci. Rev. Res. 9(1), 116-121.

Singhal, V.K., Salwan, A., Kumar, P. and Kaur, J. (2011). Phenology, pollination and breeding system of Aeglemarmelos (Linn.) Correa (Rutaceae) from India. New Forests.42, 85-100.

Stover, E. and Mercure, E.W. (2007). The pomegranate: The Pomegranate: A New Look at the Fruit of Paradise. HortScience. 42(5), 1088-1092.

Suvimol, C. and Pranee, A. (2009). Bioactive compounds and volatile compounds of Thai bael fruit [Aeglemarmelos (Linn.) Correa] as a valuable source for functional food ingredients. International Food Research Journal. 15(3), 1-9.

Vardi, A., Levin, I. and Carmi, N. (2008). Induction of seedless-ness in Citrus: from classical techniques to emerging biotechnological approaches. J. Am. Soc. Hortic. Sci. 133(1), 117-126.

Venkatesh, Y.S.S., Ordonez, N.G., Schultz, P.N., Hickey, R.C., Goepfert, H. and Samaan, N.A. (1990).Anaplastic carcinoma of the thyroid. A clinicopathologic study of 121 cases. Cancer. 66, 321-330.

Wertheim, S.J., De Jager, A. and Duyzens, M.J.J.P. (1986).Comparison of single-row and multi-row planting systems with apple, with regard to productivity, fruit size and colour, and light conditions. Acta Hort. 160, 243-260.

Yao, J.L., Dong, Y.H. and Morris, B.A.M. (2001). Parthenocarpic apple fruit production conferred by transposon insertion mutations in a MADS-box transcription factor. Proc. Natl. Acad. Sci. U.S.A. 98(3), 1306-1311.

Zhang, G., Sebolt, A.M., Sooriyapathirana, S.S., Wang, D., Bink, M.C.A.M., Olmstead, J.W. and Iezzoni, A.F. (2010) Fruit size QTL analysis of an $F_{1}$ population derived from a cross between a domesticated sweet cherry cultivar and a wild forest sweet cherry. Tree Genet. Genomes. 6, 25-36. 